\title{
Releasing Silent Texts: Narratives of Reflective Arts Performance and Special Needs Education
}

\author{
LORNA RAMSAY \\ Simon Fraser University
}

\begin{abstract}
Narratives lie in metaphorical spaces of exchange that encourage release of silent texts, spaces where voice is aesthetic reflection in performance, expression of vulnerable and embodied pedagogy of daily living and learning. I share my fictional and non-fictional autobiographical narratives of a special needs student while questioning teaching practices and re-viewing blurred borders between self-made definitions of educator, learner, and researcher. With undergraduate university education students, I share narratives of my work with special needs children as I explore invested reflective silent spaces in re-listening and re-hearing beyond fringes of the teacher/student relationship. Students share narratives of vulnerability, self-reflective re-bearing with image and sound, multi-layers of storytelling in separate and shared living landscapes.
\end{abstract}

I (re)search through musical forms and non-forms in landscapes at my ocean home accessing nuances of motion and emotion through embodied rhythms of breathing while absorbed in photographic imagery, flute playing, swimming, and writing. As I demonstrate processes of reflective arts practices, I invite my students to assume responsibility for their positioning in aesthetic spaces, in expected and unexpected sources of voice, in silence between embodied sounds and sound imagery of many layered texts in our separate and shared landscape. I invite critical reflection in sources of embodied voice in moments of creating and performing where students risk new portals of aesthetic expression in vulnerable, often discomforting, and always unresolved processes of learning, knowing, and feeling.

\section{Overture}

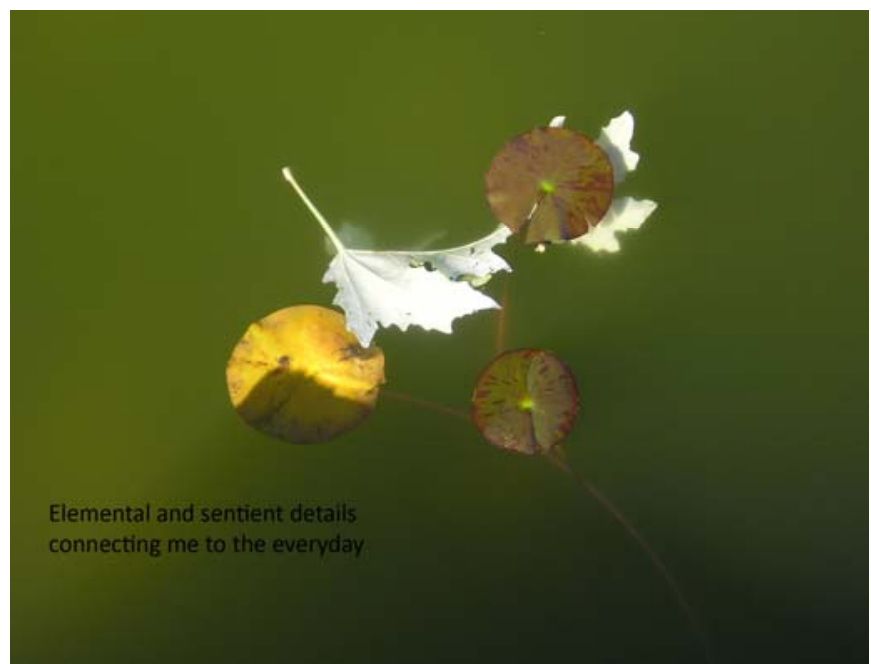

(C) Copyright 2009. The author, Lorna Ramsay, assigns to the SFU Educational Review the right of first publication and educational and non-profit institutions a non-exclusive license to use this document for personal use and in courses of instruction provided that the article is used in full and this copyright statement is reproduced. Any other usage is probibited without the express permission of the author. 
I perform my inquiry into texts of phenomenological imagery and sound-full silence, my voice 'being' present in moments before expression, in my poetry and photographic re-visioning of pedagogical challenges, 'being present' and taking in daily living inquiry (Heidegger, 1985). My pedagogy exists in 'being present with a knowing' of elemental and sentient details connecting me to the everyday, a phenomenology that Martin Heidegger says requires "in-being" (p.161). I seek an inbeing in this narrative journey, an arts performance of new profiles and informative silhouettes of reflection. This journey weaves together narratives of in-being: my flute music in moments of photographic and poetic imagery, sound, and silence; silent texts released in narratives shared with a student who finds voice through dance; and on-going processes of inquiry into my life experiences as musician/artist/author, primary teacher of special needs students, university instructor and academic researcher.

\section{Allegro non troppo: Dawn trusts her body to tell a story in her special way.}

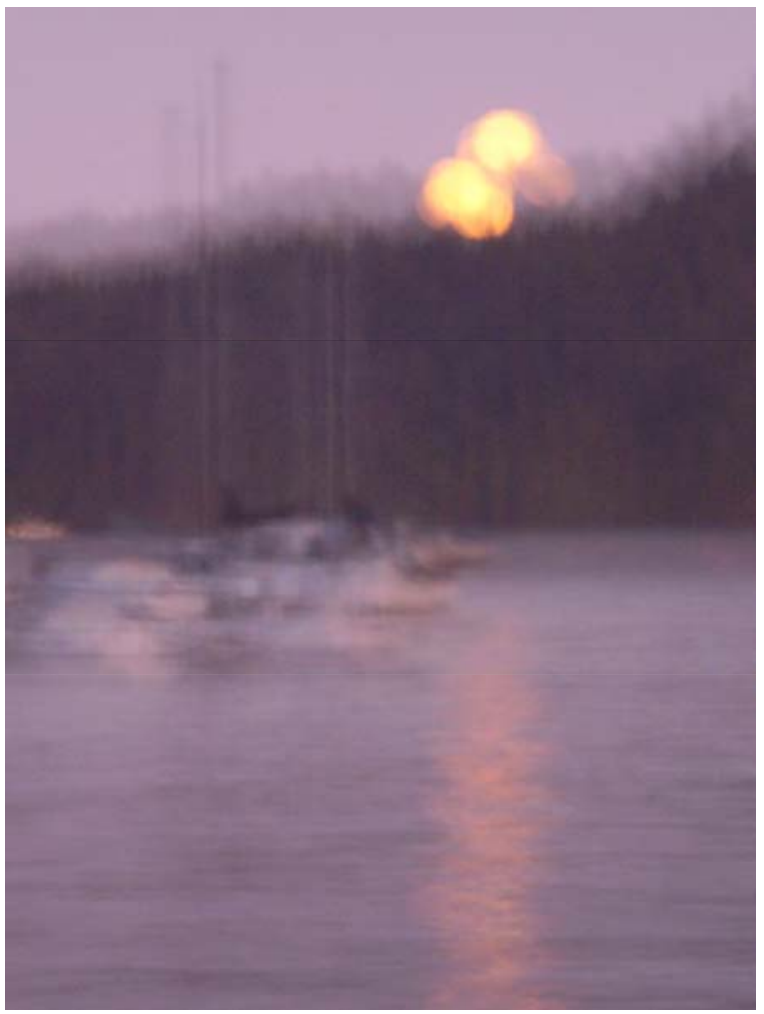

Dawn swims in strokes around and around the classroom, soaked in pleasure, laughing. A story races through her mind and, with no effort or inhibition; Dawn trusts her body to tell a story in her special way. Her mum looks apologetically at me, but I observe, through her glance, a sense of pride.

Dawn does not communicate well with others, the mum says.

I look at Dawn dancing texts of poetry.

Arms angled like wings

intense and intent

to touch landscapes of solid earth, shifting in

waves

engaged meandering messages

of open air and ocean current

our dance mingled with un-silent text

and the next message of chance and change 


\section{Andante: The listener determines what can be heard.}

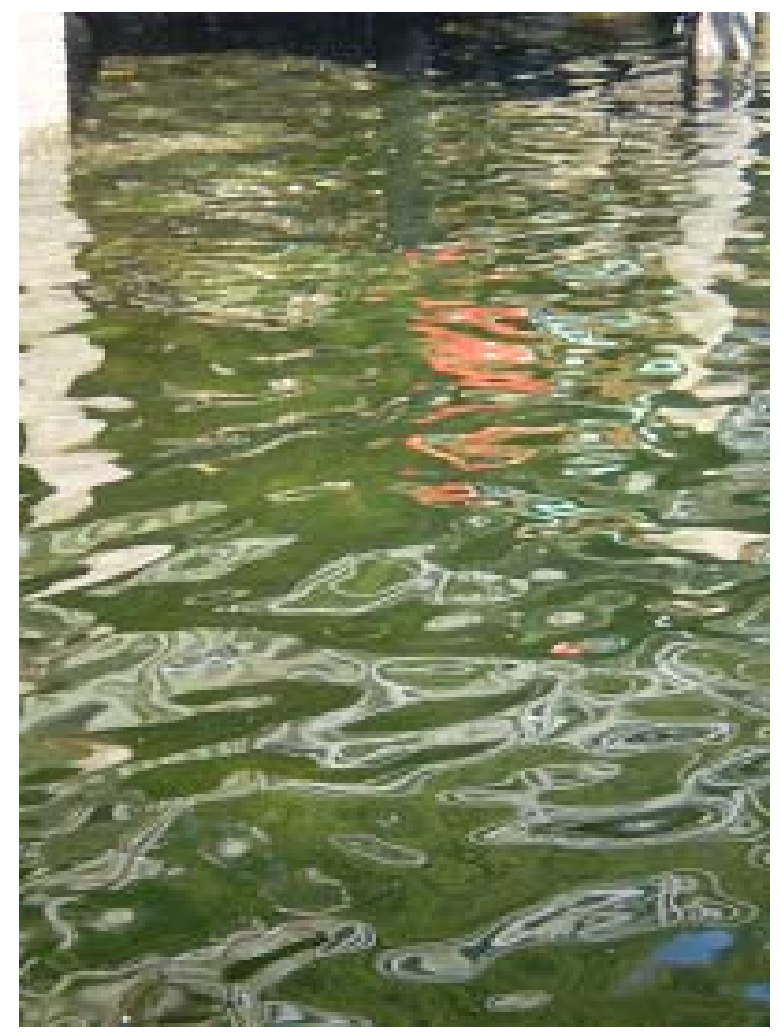

I am lost in slippery spaces of contemplation and art, spaces of inquiry. Like my Prokofieff flute sonata I look at before performing: the scherzo body-slide between tonalities, shifts of key signatures and tempi. I have on-going inquiry with moments of silent texts, the black and white notes I hear before playing, eighth rests, here and there. I think of Dawn and realize that I am like Wilson (2004) who writes, "I prefer the term fluid spaces, as if the lines between art as practice and art as research flow back and forth, and in an out, each influencing, directing, and informing the other" (p. 47). Like Wilson, I prefer spaces of undependable form.

\section{Andante meno mosso: "We wanna hear them musics."}

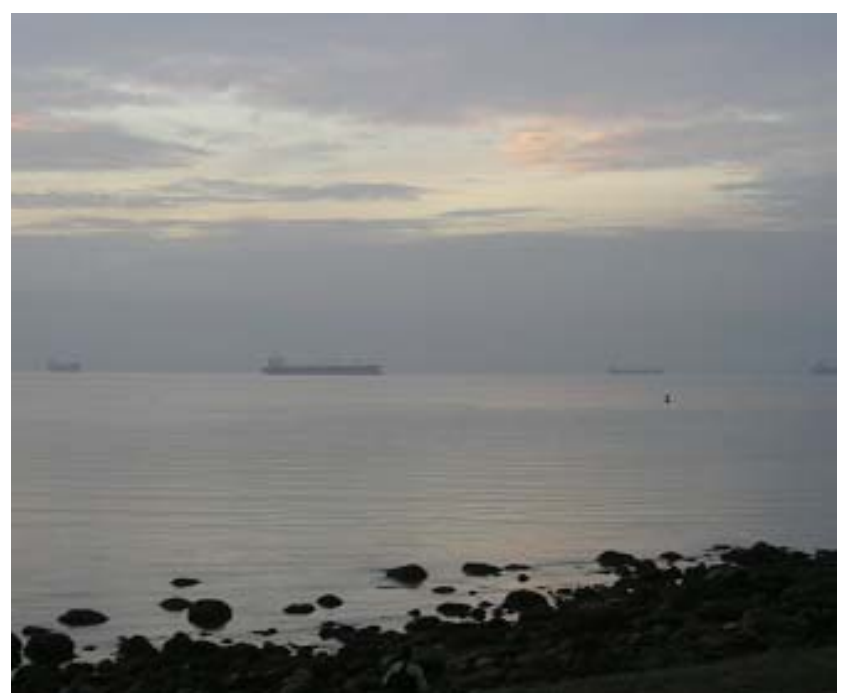


We sit on the little tables watching Dawn for a few minutes. Then, I place my hand on the mum's arm and say, Let's ask Dawn if she will share what she hears, and share her music, her story, with the whole class.

The Head Teacher enters the room and nervously looks at the clock, the parents in the room, and the children who are beginning to settle. She announces the beginning of class. My smile sweeps the room from one person to another.

The class of five-year-olds settles in their assigned spots on the carpet. I hold Dawn's hand and sit down with her at her spot. I guide her face to mine and remind her about her dancing around the room.

You went like this. You heard music. May we please hear it? I sign, as I demonstrate her swimming motion.

Dawn is shy and looks over very large glasses at her friends. friends.

Yea, Dawn, we wanna hear them musics, says Freddy, one of Dawn's very close playtime

I announce that Dawn has agreed to show us her music and that any parent who wishes to stay is welcome for a two minute concert.

Dawn begins to hum very softly. She rocks, and then, I rock. She signs, Sing, please. So, I hum with her. She begins to sing in word-forms. I harmonize softly. The other children sit transfixed. They have never heard any sounds from Dawn except in frustration.

After two minutes, I put my hand on Dawn's lap and sign, Mother. Dawn waves good-bye and signs, I love you. Mum leaves with a couple of other parents and the Head Teacher. They look back at me at the door, all with versions of their own non-verbal expression.

\section{Moderato}

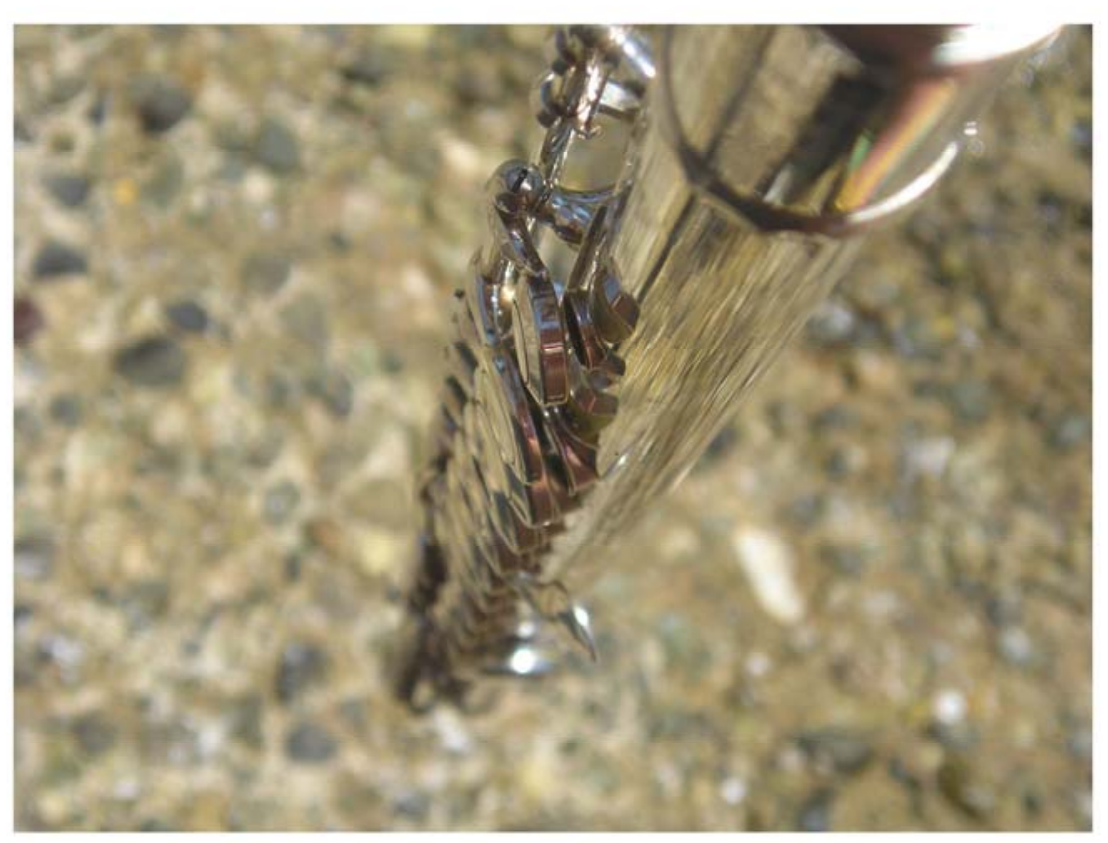

\section{Pedagogy in my movement through separate and shared spaces}

My narrative about Dawn questions structures of expected learning and knowing. With my undergraduate education students, we discuss Dawn and the 'invitation' to converse in new pedagogy, pedagogy in movement through separate and shared spaces. An anxious mother is hesitant about a new teacher and apprehensive that I would not understand her child's behaviour, connections and expressions of a body interconnecting with sound landscapes in her 'non-verbal' world. Even though I am introduced to parents as a music specialist experienced working with 
special needs children, the mum has concerns that her Down's Syndrome daughter will not find a place to feel comfortable in my scheme of work. My scheme of work is phenomenology, inquiry of temporal and physical spaces in our daily life, inquiry of sentient, visceral motion and sound, stillness and silence in a shared and reciprocating landscape where "[w]e can perceive things at all only because we ourselves are entirely a part of the sensible world that we perceive! We might as well say that we are organs of this world, flesh of its flesh, and that the world is perceiving itself through us" (Abram, 1996, p.69)

My university students point out that I am also under the scrutiny of a Head Teacher who determines success by predictable outcomes. If a class does not begin on time, then the children will take more time to settle and have problems engaging in the main morning lesson. I do not disagree with my Head Teacher, I merely out-step boundaries of prescribed imposed schedules and schemes of work with careful aesthetic awareness, observation that allows a hearing and exchange of sentient interaction with elements of a broader landscape, a viscerally aesthetic landscape.

The education students query concepts of pedagogical formulas for curriculum planning. I respond with questions similar to those posed by Eisner (1997) to educational researchers: "How do we display what we have learned? What forms of research can we trust? What modes are legitimate? How shall we know?" (p. 8). My inquiry is a negotiation of curriculum with Dawn, an autobiographical inquiry I share with future teachers where teaching practices are questioned and resolution is elusive.

\section{Scherzo}

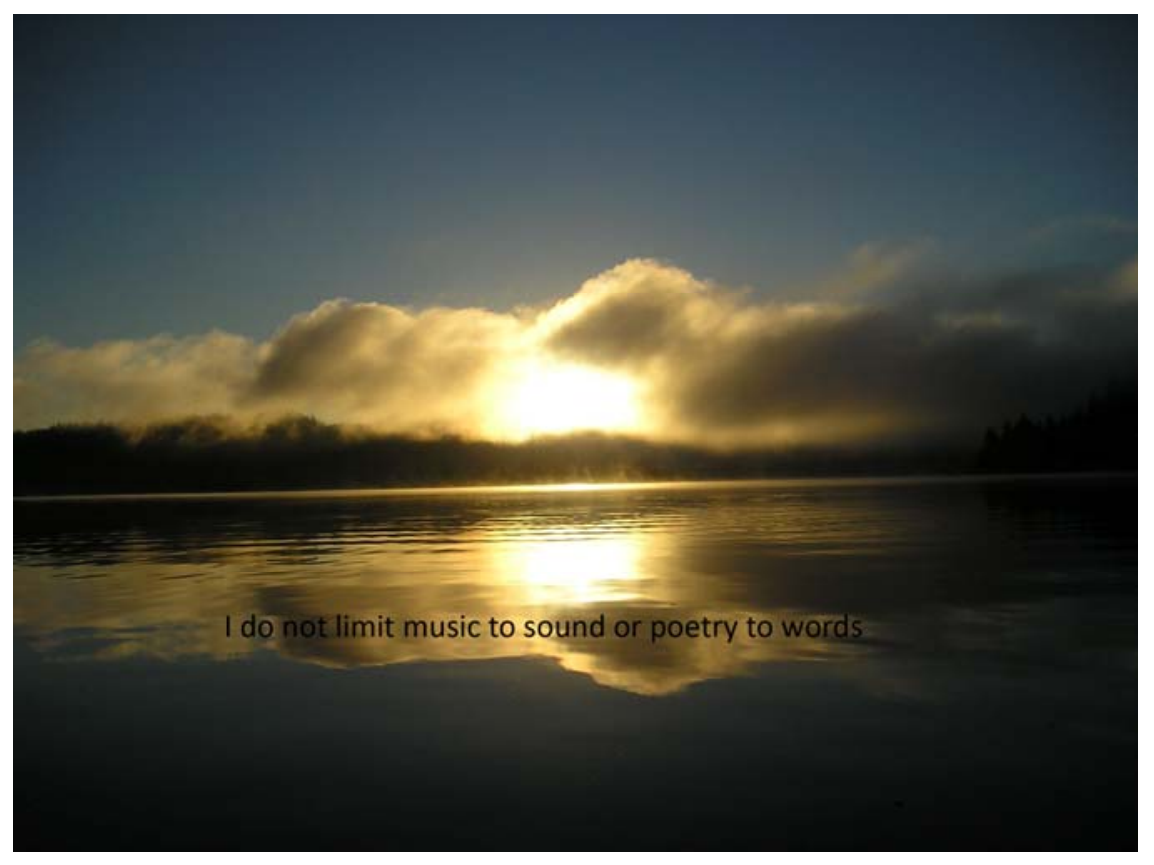

Dawn's classmates begin to title Dawn's sharing as The Morning of the Big Swim. We continue singing through registration, each child singing in different intervals that matches mine, as a morning greeting. We hum through choosing a partner to take the register to the office, and we appoint musical tones to our new phonics sounds of the morning. As a group of children sing in harmony with two phonetic sounds, I write and sing the purpose of our morning's literacy class. When the Head Teacher enters the class later in the lesson, the goals of the lesson have been met and the children are at their tables matching sounds with words, interacting with new combinations of sounds in a discovery of their voices. Just before the break, we share our sounds of the day and all the new combinations. Dawn and her Teaching Assistant share their musical discoveries in a performance that matches the early morning playful enthusiasm. 
When I think of Dawn's expressive nature, I feel and urge for humour and playfulness. Reminded of how I approach my next flute sound in the Prokofieff scherzo, realizing it was originally a scherzando, I hold back. I play slowly, trying to remember notes and tonality, trying too hard, hearing nothing. Then, I let go, and play whatever I want. Like Dawn, I take risks. I listen to Jardine (1992), "Losing one's way, loss, and letting go are inherent in the creative process, because it's in the letting go that we find......an undetermined adventure that we experience the 'vibrant difficulty"' (p. 126).

I consider a balance between scheduled hearing and my improvisational mind. I reach to access something special, something only I can reveal. I am skilled, yet I know there is more. To access my voice is to invest in silence and my contemplation. I stop to observe Prokofieff's text of intention and expectation, and, in a moment without sound, I know I have the required skills. What I do with my skills as a musician, or, my skills as an educator, is determined by the extent of my listening. I hear my flute playing, octave jumps of the most difficult note for a flutist, the scherzo joke that I may crack high $\mathrm{E}$ and land, instead, firmly on middle A. I listen seriously to my wandering improvisation with B Flat arpeggios and scale passages of dubious tonality. I listen to restorative silence between notes, between tempo changes, between my breaths resonating agency of new pedagogy. When I think of myself as an educator, I think of 'listening silence" (O' Reilly, 1996, p.31), the place from which words emerge.

I invite my undergraduate education students to challenge teaching practices and traditional approaches to disability, teaching language, and literacy and numeracy, approaches that operate “...from practices already constructed" (Waters, 1994, p. 52) by “...presupposed cultures and social realities” (Burnard \& Hennessey, 2006, p. 48). My invitation includes an offer to observe and see, listen and hear, and viscerally collaborate with me in narrative reflective spaces of arts performance as learning and teaching. I explain that my challenge with Dawn and her friends is to perceive our shared landscape while mutually respecting separate spaces. In doing so, I extend our class experience to directed goals of learning. I use music and movement, tonality in multi-textures of knowing, to bind purposes and goals with performative moments of expressing and learning, only because I do not limit music to sound and poetry to words.

Later in the week of the "The Morning of the Big Swim", in circle time, Dawn stands up with a picture she has drawn. Dawn speaks to the class using two full sentences.

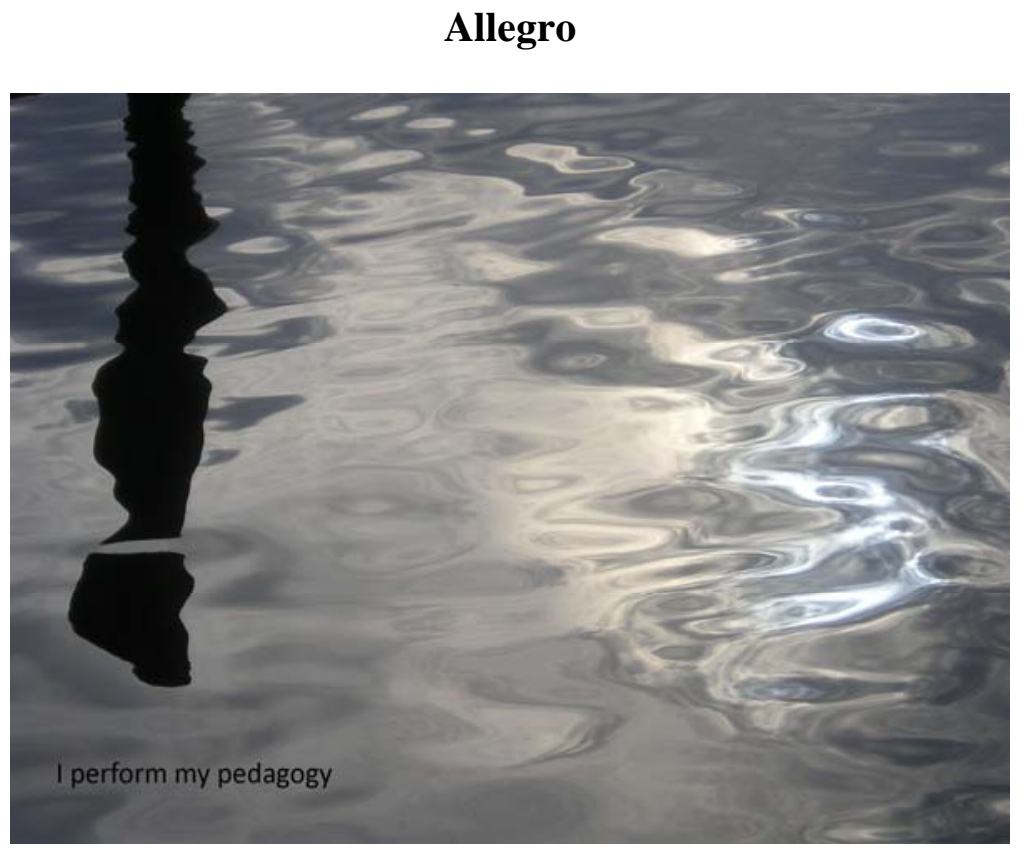

Performance is my release from what is predictable and certain in pedagogical spaces between art and teaching, both in primary academic and arts education, and, particularly, music, as part of an arts 
inclusive curriculum. In this release, I seek agency for each performer ".. to tap into imagination.... (and)... to break with what is supposedly fixed and finished, objectively and independently real. It is to see beyond what the imaginer has called normal or "common-sensible" and to carve out new orders in experience. Doing so, a person may become freed to glimpse what might be..." (Greene, 1995 , p. 19). My experience as a programmer developer for special needs students offers me opportunities to seek, in my improvisational teaching places, malleable, vulnerable places of learning. In these places, practical teaching practices carve new portals through well-used gauges of aesthetic expression and musical development as indicators of cognitive, artistic, and aesthetic growth, terms gauging 'imagination', 'creativity', and, 'intuition'.

\section{Coda: Reflective performance}

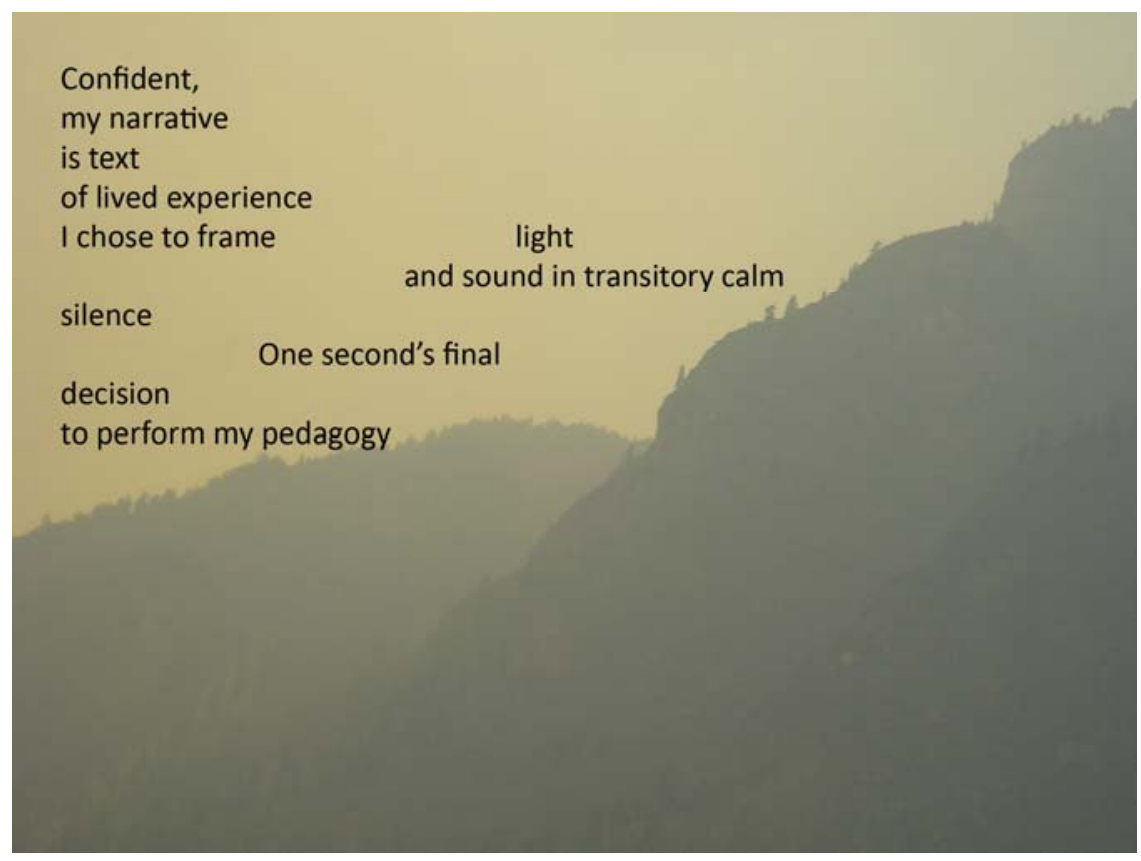

I sort through my repertoire and, if I try too hard, I hear nothing. I remember Prokofieff and repeated passages toward the end of the scherzo. I wander past the A Flat Minor arpeggios where I begin to improvise. Looking further along the staff, I realize the scherzo ends in sharp, staccato leaps. I feel hopeful. I feel joy. Yet, as I shift from my choice of tones and sensibilities and bring my improvised hope to the next demanding text, I take on an allegro finale and I feel apprehensive uncertainty. I feel ambiguity, part of what Irwin and de Cosson (2004) describe as a process of circling hermeneutical movements, not fixed goals, a relational praxis of bridging and traversing spaces. He writes, "We are not found until we are lost. We feel the pull to stop and the pull to continue" (Irwin \& de Cosson, 2004, p. 202). This is how I feel introducing new choices for Dawn, releasing silent texts and transforming activities according to spaces of Dawn's corporeal listening and hearing, Dawn's voice. I improvise through my everyday understanding of what potential may be, just as I shift sounds playing my flute in interrupted darkness of an August full moon on the ocean, each note shimmering improvisational nature of undulating tonality. When I perform my pedagogy, who is the performer? Who is the observer?

\section{References}

Abram, D. (1996). The spell of the sensuous. New York: Random House.

Burnard, P., \& Hennessy, S. (Eds.) (2006). Reflective practices in arts education. Dordrecht, The Netherlands: Springer. 
Eisner, E. W. (1997). The promise and perils of alternative forms of data representation. Educational Researcher, 26 (6), 4-10.

Greene, M. (1995). Releasing the imagination: Essays on education, the arts, and social change. San Francisco: Jossey-Bass.

Heidegger, M. (1985). History of the concept of time. Bloomington: Indiana University Press

Irwin, R., \& de Cosson, A. (Eds.) (2004). a/r/tography: Rendering self through arts-based living inquiry. Vancouver: Pacific Educational Press.

Jardine, D. (1992). Reflections and education, hermeneutics, and ambiguity: Hermeneutics as restoring life to its original difficulty. In W. F. Pinar \& W. M. Reynolds (Eds.) Understanding curriculum as phenomenological and deconstructed text (pp. 116-130). New York: Teachers College Press.

O’Reilly, M. R. (1998). Radical presence: Teacbing as contemplative practice. Portsmouth, NH: Boynton/Cook.

Waters, M. (1994). Modern sociological theory. London: Sage.

Wilson, S. (2004). Fragments: Life writing in image and in text. In R. Irwin \& de Cosson (Eds.)

A/r/tography: Rendering self through arts-based living inquiry (pp. 41-59). Vancouver, Pacific Educational Press.

\section{About the Author}

I am a musician, poet, photographer and educator with experience in special education. Inviting knowledge of who I am as an artist/learner/educator means researching my embodied voice, developing imaginative portals around borders of my identities that blur structures of accepted and expected schemes of learning. As I play my flute, write, and swim near my ocean home, I research teaching as performance and learning as embodied, corporeal expression. I am a mother of four sons.

Lorna Ramsay

llramsay@sfu.ca 